\title{
PERLINDUNGAN HUKUM TERHADAP PELAKU UMKM KULINER DI KABUPATEN BEKASI
}

\author{
Bella Ftria Ariyanti*1 ${ }^{1}$, Ranissa sekar elaies ${ }^{2}$, Allya putri yuliyani ${ }^{3}$, Jeane Neltje Saly ${ }^{4}$ \\ ${ }^{1}$ Jurusan Hukum,Universitas Tarumanegara \\ Email : bella.205210013@stu.untar.ac.id \\ 2 Jurusan Hukum Universitas Tarumanegara \\ Email : ranissa.205210314@stu.untar.ac.id \\ ${ }^{3}$ Jurusan Hukum Universitas Tarumanegara \\ Email : allya.205210312@stu.untar.ac.id \\ ${ }^{4}$ Jurusan Hukum Universitas Tarumanegara \\ Email : jeanes@fh.untar.ac.id
}

\begin{abstract}
Looking at the various current conditions of the country caused by the COVID-19 pandemic, the impact on economic sectors in Indonesia became unstable. But thanks to the support of MSMEs and the government, the economy in Indonesia can soon recover. Efforts made by the government with various programs for MSMEs, especially in Bekasi Regency, which have innovated related to changes in people's behavior due to COVID-19, related to changes in people/consumers' behavior in buying and selling online, business actors have utilized technology digitally. Therefore, social media and market place become a solution to make it easier for MSMEs to get wider marketing access to make it easier for businesses to reach consumers/buyers globally. In compiling this article, the author first researched to obtain information or data after this article is the result of normative legal research whose implementation is focused on the use of secondary data by using a qualitative paradigm approach of management, and data collection is done qualitatively using deductive logic where the laws and regulations are placed as major premises and facts are placed as the premise of the s minor (Soerjono S, 2007:52). So that this method is more directed to the proof of a theory that already exists. This research also makes a comparison of what can be done to get the most appropriate solution while through a secondary approach researchers refer to laws and regulations, papers, and articles to find out the information that already exists with related problems. This aims to find out the role of the government in protecting MSMEs during the pandemic and how MSMEs in the Bekasi Regency innovate to survive amid the current pandemic.
\end{abstract}

Keywords: MSMEs, Covid-19 pandemic, Innovation, Government Role, Digital.

\begin{abstract}
ABSTRAK
Melihat dari berbagai kondisi Tanah Air saat ini yang diakibatkan oleh pandemi COVID-19 sehingga berdampak pada sektor-sektor perekonomian di Indonesia menjadi tidak stabil. Namun berkat dukungan UMKM dan pemerintah, perekonomian di Indonesia dapat segera pulih kembali. Upaya yang dilakukan pemerintah dengan berbagai program untuk pelaku UMKM khususnya di Kabupaten Bekasi yang telah melakukan inovasi terkait perubahan perilaku masyarakat akibat COVID-19, terkait perubahan perilaku masyarakat/konsumen dalam melakukan jual-beli secara online para pelaku usaha telah memanfaatkan teknologi secara digital. Oleh karena itu Media sosial dan market place menjadi sebuah solusi untuk mempermudah pelaku UMKM mendapatkan akses pemasaran yang lebih luas agar memudahkan para pelaku usaha untuk menjangkau para konsumen/pembeli secara global. Dalam menyusun artikel ini penulis terlebih dahulu melakukan penelitian untuk mendapatkan informasi atau data sehigga artikel ini adalah hasil dari penelitian hukum normative yang pelaksanaannya difokuskan pada penggunaan bersifat data sekunder dengan menggunakan pendekatan paradigma kualitatif pengolaan dan pengumpulan data dilakukan secara kualitatif dengan menggunakan logika deduktif dimana peraturan perundangundangan ditempatkan sebagai premis mayor dan fakta-fakta ditempatkan sebagai premis minor. Sehingga metode ini sifatnya lebih mengarah kepada pembuktian atas sebuah teori yang telah ada. Penelitian ini juga menjadikan perbandingan tentang apa yang dapat dilakukan untuk mendapatkan sebuah solusi paling tepat sedangkan melalui pendekatan sekunder peneliti mengacu pada peraturan perundang-undangan, makalah, serta artikel-artikel untuk mengetahui informasi yang telah ada dengan masalah yang terkait.. Hal ini bertujuan untuk mengetahui apa saja peran pemerintah dalam melindungi pelaku UMKM selama pandemi serta bagaimana pelaku UMKM di Kabupaten Bekasi melakukan inovasi agar bertahan di tengah pandemi saat ini.
\end{abstract}

Kata kunci : UMKM, Pandemi Covid-19, Inovasi, Peran Pemerintah, Digital. 


\section{PENDAHULUAN}

Negara Kesatuan Republik Indonesia adalah negara yang menjunjung tinggi asas keadilan sosial seperti yang tertuang dalam pembukaan UUD Negara Republik Indonesia yang mengatakan negara menjamin kesejahteraan umum. Menurut UU No. 20 tahun 2008 tentang Usaha Mikro, Kecil dan Menengah (UMKM) merupakan suatu wirausaha yang dijalankan individu atau badan usaha berskala kecil yang dikategorikan sesuai aset serta jumlah kekayaaan bersih/omzet setiap tahun. UMKM sendiri penyumbang terbesar pertumbuhan perekonomian di Tanah Air.

UMKM juga termasuk penyumbang paling banyak lapangan pekerjaan khususnya pada kondisi pandemi saat ini. Penularan virus COVID-19 pada awal tahun 2020 membuat sektor perekonomian RI menjadi terjun bebas dan berdampak buruk pada berbagai sektor. Walaupun Indonesia pernah mengalami krisis ekonomi pada tahun 1997 sampai dengan tahun 1998 namun hanya UMKM yang dapat bertahan dan membantu memulihkan perekonomian..

Data survei kajian cepat yang dilakukan oleh Pusat Penelitian Ekonomi LIPI menunjukkan bahwa selama pandemi COVID-19, sebanyak 94,69\% UMKM (Agus Eko N, 2021) mengalami depresiasi penjualan yang menyebabkan sulitnya melunasi pembayaran listrik, gas, serta upah pegawai sehingga banyak diantaranya melakukan pemecatan berakibat terjadi pengurangan pegawai. Masalah lain yang dirasakan oleh pelaku UMKM antara lain adalah biaya produksi yang tetap atau bahkan bertambah namun sulitnya memperoleh pemodalan. Oleh karena itu peran pemerintah sangat dibutuhkan pada situasi saat ini, seperti penambahan bantuan dana, keringanan pembayaran listrik dan dorongan/dukungan lainnya.

Kemenko Perekonomian RI melalui Pers No. HM.4.6/88/SET.M.EKON.3/04/2021 tentang "Dukungan Pemerintah Bagi UMKM Agar Pulih di Masa Pandemi", dalam isinya tersebut pemerintah sudah mempersiapkan insentif bantuan untuk UMKM via program PEN yang diberikan pada tahun lalu dan akan dilanjutkan pada tahun ini (haryo limanseto, 2021). Dana sejumlah 112,84 triliun rupiah sudah dirasakan oleh 30 juta lebih pelaku usaha yang diberikan pada tahun lalu dan tahun ini pemerintah sudah menganggarkan modal sejumlah 121,90 triliun rupiah untuk melindungi kontinuitas perbaikan ekonomi.

Pandemi COVID-19 ini menyebabkan perilaku konsumen berubah. Hal ini dikarenakan para konsumen lebih sering menghabiskan aktivitas dan waktunya di rumah dan menurunnya daya beli masyarakat, perubahan yang sangat kontras dan cepat memaksa perusahaan atau pelaku UMKM untuk mencetuskan ide atau pola baru dalam memasarkan dan mempromosikan produkproduknya sehingga lebih mudah dijangkau oleh para konsumen/pembeli.

Sektor UMKM yang berhasil bertahan di tengah wabah khususnya saat PPKM adalah mereka yang mampu beradaptasi dan memiliki kreatifitas untuk bertransformasi seperti banyaknya pelaku UMKM di Bekasi yang semakin gencar berinovasi dalam teknologi yang berbasis sinyal elektrik komputer. Berdasarkan hasil sensus ekonomi di Kota Bekasi, 2016 (SE2016), terhitung 203.056 unit UMKM non-pertanian yang diklasifikasikan sebanyak 15 jenis lapangan usaha sesuai dengan "Klasifikasi Baku Lapangan Usaha Indonesia (KBLI) 2015", sejumlah 89.621 unit atau 44,14 persen didominasikan para pelaku usaha pedagang besar dan eceran (bekasi kota, 2017).

Menurut Kepala Dinas Perindustrian di Kabupaten Bekasi, Peno Suyatno, menyatakan UMKM di Kabupeten Bekasi masih bertahan di tengah wabah virus COVID-19 ini, dikarenakan jumlah paling banyak pelaku UMKM di sini mempromosikan produknya berbasis komunikasi online/daring. Disamping itu para pelaku UMKM di Bekasi memanfaatkan Bantuan Presiden (BANPRES) yang merupakan salah satu program dari "Pemulihan Ekonomi Nasional (PEN)" dipublikasikan oleh Presiden Jokowi pada tanggal 24 Agustus 2020 lalu sejumlah 2,4 Juta rupiah per pelaku usaha yang diberikan 1 (satu) kali melalui bank penyalur kepada rekening pelaku 
usaha yang bersangkutan (Muhammad Azzam, 2020). Banpres sendiri merupakan bantuan yang diberikan kepada pelaku UMKM dengan tujuan agar UMKM bisa tetap berjalan di tengah krisis akibat wabah virus COVID-19.

Menkop Usaha Kecil Menengah Teten Masduki, dalam konferensi persnya yang diselenggarakan pada tanggal 07 Oktober 2020 di Kantor Presiden memberikan keterangan bahwa program ini cepat terserap dan karena proses pemeriksaan data cukup ketat membuat program ini tepat sasaran serta berkat dari berbagai dukungan seperti Himpunan Bank Milik Negara/Himbara, pemerintah daerah, Koperasi dan lembaga lain yang mendukung UMKM.

\section{Rumusan Masalah}

Dari permasalahan yang sudah disebutkan dapat diidentifikasikan rumusan masalah sebagai berikut:

1. Bagaimana peran pemerintah memberdayakan pelaku UMKM selama pandemi COVID -19?

2. Langkah-langkah apa yang dilakukan pelaku UMKM di Kabupaten Bekasi selama pandemic COVID-19?

\section{METODE PENELITIAN}

Penelitian dalam penulisan artikel ini dengan metode penelitian hukum normatif yang pelaksanaannya difokuskan pada penggunaan data sekunder dengan menggunakan pendekatan paradigma kualitatif pengolaan dan pengumpulan data dilakukan secara kualitatif dengan menggunakan logika deduktif dimana peraturan perundang-undangan ditempatkan sebagai premis mayor dan fakta-fakta ditempatkan sebagai premis minor (Soerjono S, 2007:52).

\section{HASIL DAN PEMBAHASAN}

\section{Peran Pemerintah Dalam Memberdayakan UMKM}

Peran pemerintah dalam memberdayakan UMKM merupakan pelaksanaan demokrasi ekonomi yang tertuang pada Pasal 33 ayat (4) UUD 45, mengandung sila kelima Pancasila. Tujuannya untuk mengimplementasikan keadilan berusaha bagi pelaku usaha. Tidak hanya Usaha Bermodal Besar (UB) tetapi juga UMKM turut berperan menunjang pembangunan ekonomi.

Upaya pemerintah memberdayakan UMKM sangat berpengaruh dan penting bagi perekonomian negara. Lebih dari 60 persen penyumbang PDB terbesar adalah UMKM. Hal itu disebabkan karena UMKM merupakan sektor yang lebih banyak jumlahnya dibanding sektor usaha bermodal besar, sekitar 64 juta UMKM dibandingkan sektor usaha lain yang ada di Indonesia dan memiliki kelebihan penyuplai tenaga kerja yang bermanfaat sebagai upaya pengurangan jumlah pengangguran di Indonesia (Pratiwi Agustini, 2020).

Semenjak terjadinya pandemi COVID-19 di seluruh dunia, perekonomian global semakin turun secara signifikan tak terkecuali di negara Indonesia, UMKM menjadi pilar pembangunan perekonomian, sebagaimana krisis moneter yang terjadi pada tahun 1997-1998 dimana ekonomi di tanah air sama-sama sedang mengalami penurunan dan hanya UMKM lah yang bertahan pada kala itu. Hal itu merupakan hasil kajian cepat oleh LIPI yang dilakukan selama dua puluh hari terhitung pada tanggal 1-20 Mei tahun lalu secara berbasis komunikasi secara online/daring dan mengikutsertakan 679 peserta untuk mengetahui dampak pandemi pada kelangsungan sektor UMKM di Indoensia.

Tabel berikut menunjukkan keberadaan UMKM pada berbagai sektor usaha: 
Tabel 1. Responen Pelaku UMKM

\begin{tabular}{clc}
\hline NO. & Responden pelaku usaha & \% \\
\hline 1. & Mikro & $54,98 \%$ \\
\hline $2 .$. & Ultra mikro & $33,02 \%$ \\
\hline 3. & Usaha kecil & $8,1 \%$ \\
\hline 4. & Usaha menengah & $3,89 \%$ \\
\hline
\end{tabular}

Sumber : data LIPI, 2020

Berdasarkan tabel 1 responden pelaku usaha terdiri dari usaha mikro, ultra mikro, usaha kecil, dan usaha menengah dengan lamanya usaha untuk 0-5 tahun 55,2\% (lima puluh lima koma dua persen), 6-10 tahun 24\% (dua puluh empat persen), dan lebih dari 10 tahun 20,8\% (dua puluh koma delapan persen). Sebanyak 58,36\% (lima puluh delapan koma tiga enam persen) usaha yang berusia 0-5 tahun berada dalam skala ultra-mikro dan sebanyak 58,33\% (lima puluh delapan koma tiga tiga persen) untuk skala mikro serta metode penjualan paling tinggi yaitu sebanyak 54\% (lima puluh empat persen) dilakukan melalui akun media sosial.

Hasil survei yang dilakukan Lembaga Ilmu Pengetahuan Indonesia (LIPI), diketahui bahwa sebanyak 94,69\% (sembilan puluh empat koma enam sembilan prsen) UMKM mengalami depresiasi penjualan yang menyebabkan sulitnya melunasi pembayaran listrik, gas, serta upah pegawai sehingga banyak diantaranya melakukan pemecatan/pengurangan jumlah pegawai karena tidak seimbangnya biaya pemasukan dan pengeluaran (Agus Eko N, 2021). Maka dari itu dalam siaran pers Kemenko Perekonomian RI melalui Pers No. HM.4.6/88/SET.M.EKON.3/04/2021 tentang "Dukungan Pemerintah Bagi UMKM Agar Pulih di Masa Pandemi", dalam isinya tersebut pemerintah sudah mempersiapkan insentif bantuan untuk UMKM via program "Pemulihan Ekonomi Nasional (PEN)" pada tahun lalu dengan modal sejumlah 112,84 triliun rupiah sudah dirasakan oleh 30 juta lebih pelaku usaha dan akan dilanjutkan pada tahun ini, pemerintah sudah menganggarkan modal sejumlah 121,90 triliun rupiah.

Upaya yang telah dilakukan pemerintah dalam memberikan dukungan antara lain bantuan Presiden Produktif (Banpres Produktif) merupakan program PEN. Banpres Produktif merupakan bantuan yang diberikan untuk pelaku UMKM dengan tujuan agar pelaku usaha tetap bisa berjalan ditengah krisis akibat wabah virus ini, dilucurkan oleh Presiden Jokowi pada tanggal 24 Agustus 2020 lalu sejumlah 2,4 Juta rupiah per pelaku UMKM diberikan 1 (satu) kali melalui bank/lembaga penyalur kepada rekening pelaku UMKM yang bersangkutan (Muhammad Azzam, 2020).KK. Banyak dari pelaku UMKM di Kabupaten bekasi memanfaatkan Banpres Produktif ini. Menurut Kementerian Koperasi dan UKM di kabupaten Bekasi jumlah penerima dana bantuan presiden telah mencapai 143.390 orang dan sejumlah 91.446 penerima merupakan usulan dari Desa/Kelurahan melalui Dinas Koperasi dan UKM kabupaten Bekasi.

Adapun syarat yang harus dipenuhi oleh calon penerima Banpres adalah sebagai berikut :

1) WNI,

2) Memiliki NIK,

3) Mempunyai Usaha,

4) Non-ASN, anggota Tentara Negara Indonesia/Polri, dan non-pegawai BUMD/BUMN,

5)Tidak sedang menerima pinjaman/pembiayaan dari perbankan dan Kredit Usaha Rakyat/KUR.

Calon peneerima hanya dapat direkomendasikan oleh Lembaga Pengusul seperti Dinas yang membidangi koperasi dan UMKM Provinsi dan Kabupaten/Kota, Koperasi yang telah disahkan sebagai badan hukum, Kementerian/Lembaga, Perbankan dan perusahaan pembiayaan yang 
terdaftar di OJK serta Lembaga Penyalur Program Kredit Pemerintah terdiri dari BUMN yang menyalurkan pembiayaan atau pinjaman yang terdaftar di OJK dan BLU yang mempunyai tugas melaksanakan pengelolaan dana bergulir kepada Koperasi atau Usaha Mikro, Kecil dan Menengah.

Dengan adanya dukungan ini pemerintah berharap program Pemulihan Ekonomi Nasional (PEN) dapat mendukung pelaku usaha agar pulih dimasa wabah COVID-19 karena pemerintah telah berusaha menyiapkan berbagai program dan kebijakan agar kedepannya dapat memberikan kemudahan, perlindungan, serta pemberdayaan bagi UMKM di Indonesia (Susiwijono, 2021).

Pemerintah juga terus menggalakkan para pelaku UMKM di Kabupaten Bekasi untuk memanfaatkan platform digital karena di masa pandemi ini memaksa usaha mikro, kecil, menengah agar bangkit dengan inovasi dan teknologi. Dijelaskan juga bahwa perubahan perilaku konsumen ini berdampak pada pelaku UMKM yang belum cakap beradaptasi secara digital dan banyak dari mereka harus menutup usahanya, dengan adanya beberapa protokol kesehatan sebagian besar masyarakat telah mengurangi kegiatan mereka diluar ruangan dan menghindari kegiatan outdoor sehingga masyarakat lebih banyak beraktivitas di rumah dengan memanfaatkan teknologi digital untuk bekerja dan membeli kebutuhan rumah tangga secara online. Hal ini berdampak kepada beberapa gerai makanan yang tutup di wilayah Bekasi, Jatiwaringin karena turunnya pengunjung yang cukup drastis setiap hari.

Masyarakat saat ini akhirnya lebih banyak memilih layanan konsumen online. Hal ini tentu saja karena masyarakat ingin tetap mendapatkan pelayanan yang sesuai tanpa harus keluar rumah. Itu juga yang membuat beberapa pelaku usaha mulai berinovasi menjalankan usaha mereka melalui basis dalam jaringan atau online.

Menurut Purnomo yang dikutip dalam artikel Bambang Arianto pada tahun 2020 menjelaskan bahwa, "media sosial dan market place menjadi sebuah solusi untuk mempermudah pelaku UMKM mendapatkan akses pemasaran yang lebih luas untuk memasarkan dan mempromosikan produknya". Diharapkan permasalahan yang dihadapi pelaku UMKM dapat terselesaikan dari masalah ditutupnya tempat usaha, kurangnya pelanggan yang datang ke tempat, penurunan omzet dikarenakan jam waktu makan dikurangkan dan lain sebaginya. Dengan adanya teknologi yang maju saat ini diharapkan dapat membantu menyelesaikan permaslahan yang sudah disebutkan di atas dan dapat meningkatkan pendapatan bagi pelaku UMKM.

\section{Langkah-Langkah Yang Dilakukan UMKM}

Menurut hasil sensus ekonomi BPS tahun 2016, "jumlah UMKM di Kota Bekasi kurang lebih 203 ribu unit. Jenis usaha perdagangan pengolahan makanan dan minuman sejumlah 12,186 dengan serapan tenaga kerja sebesar 410 ribu orang pekerja pada tahun 2016. Sedangkan, per akhir Desember tahun lalu, jumlah UMKM yang memasuki ekosistem digital mencapai 3,8 juta. Bahkan, per Maret tahun ini, jumlah UMKM yang memasuki ekosistem digital kembali melonjak menjadi 4,8 juta".

Di masa pandemi, para pelaku usaha di Kabupaten Bekasi harus berinovasi agar roda perekonomian tetap berjalan sebagaimana mestinya. Tidak adanya pertahanan para pelaku usaha di kabupaten Bekasi dapat dilihat dari kurangnya inovasi dalam teknologi digital dan pemasaran. Sosial media adalah salah satu "jembatan" untuk menyambung pertahanan UMKM. Media sosial bisa digunakan untuk mempromosikan aktivitas usaha dan menghasilkan output dari hasil usaha pelaku UMKM Bekasi karena strategi pemasaran melalui media sosial dapat mendongkrak usaha.

E-commerce memudahkan untuk melakukan transaksi dan kegiatan jual-beli tanpa harus bertemu secara langsung. Proses kegiatan pembelian pun mengandalkan internet atau online oleh karena itu keuntungan yang didapat selain bisa menjaga protokol Kesehatan juga pembeli bisa mendapat 
potongan harga. Jangkauan dari e-commerce ini juga sangat luas. Inovasi Produk berpengaruh dengan arah positif terhadap keunggulan bersaing. Pengembangan inovasi kepada para pelaku UMKM di Kabupaten Bekasi juga tidak hanya tentang bagaimana cara memasarkan dan menjual produk lewat media sosial, tetapi juga memberikan ilmu bagaimana cara meningkatkan kualitas sumber daya manusia, memberi pelatihan perhitungan laba rugi, dan memiliki kebiasaan penggunaan pendapatan yang sesuai dengan kebutuhan artinya tidak boros/mubazir.

Problematik yang dihadapi kebanyakan pebisnis dari UMKM adalah pelaku yang tidak memiliki modal cukup besar, jaringan/akses yang tidak mendukung dan terlalu spesifiknya segmentasi pasar, hal ini menyebabkan para pelaku usaha dari kabupaten Bekasi mengalami banyak kendala karena adanya wabah selain itu aturan pemerintah yang membuat kebijakatan seperti terbatasnya waktu untuk makan ditempat dan keterbatasan jam oprasional juga mengakibatkan penghasilan dari pelaku usaha berkurang ditambah sulitnya mencari pinjaman modal karena bank menolak memberikan dananya kepada sektor-sektor usaha kecil dan juga Kebijakan PSBB membuat terhambatnya pergerakan dalam penyediaan bahan baku yang biasa didatangkan untuk para pelaku usaha dari kota Bekasi itu sendiri atau dari luar wilayah lain.

Untuk mengatasi problematik yang dihadapi para pelaku UMKM di Kabupaten Bekasi, diperlukan pemahaman pengetahuan dan kesadaran bahwa kemajuan usaha akan berubah sejalan dengan berubahnya perilaku konsumen. Adanya perubahan kebiasaan para konsumen/pembeli dikarenakan dorongan keadaan secara berulang-ulang/terus-menerus sehingga memerlukan waktu yang cukup lama bagi masyarakat untuk mengubah kebiasaan awal, dengan sistem pasar melalui pelayanan secara online.

1. Bagaimana peran pemerintah dalam melindungi pelaku umkm selama pandemic COVID-19?

2. Langkah-langkah apa yang dilakukan pelaku UMKM di Kabupaten Bekasi selama pandemic COVID-19?

\section{KESIMPULAN SARAN}

\section{Kesimpulan}

1. Peran pemerintah memberdayakan UMKM selama pandemi COVID-19 agar tetap eksis kegiatan usahanya merupakan pelaksanaan fungsi pemerintah atas tanggung jawab mensejahterakan rakyat dengan upaya mengimplementasi demokrasi ekonomi yang tertuang pada Pasal 33 ayat (4) UUD 45, mengandung sila kelima Pancasila.Tujuannya untuk keadilan berusaha bagi pelaku usaha, tidak hanya Usaha bermodal Besar (UB) tetapi juga UMKM turut berperan menunjang pembangunan ekonomi. Hal itu dilihat terhadap para pelaku UMKM di Kabupaten Bekasi melalui pemberian dorongan pemanfaatan platform digital agar bangkit dengan inovasi dan teknologi. Selanjutnya dukungan Pemerintah Bagi UMKM agar pulih di masa Pandemi", dengan insentif bantuan untuk UMKM via program "Pemulihan Ekonomi Nasional (PEN)" pada tahun lalu dengan modal sejumlah 112,84 triliun rupiah yang dirasakan oleh 30 juta lebih pelaku usaha dan akan dilanjutkan pada tahun ini, melalui komitmen menganggarkan modal sejumlah 121,90 triliun rupiah.

2. Langkah-langkah yang dilakukan UMKM untuk mengatasi problematik yang dihadapi dari kebanyakan mereka untuk mengatasi kekurangan modal, jaringan/akses yang tidak mendukung dan terlalu spesifiknya segmentasi pasar, sebagaimana para pelaku usaha di kabupaten Bekasi, juga aturan pemerintah yang membuat kebijakatan seperti terbatasnya waktu untuk makan ditempat dan keterbatasan jam oprasional yang berdampak berkurang pemasukan, ditambah sulitnya mencari pinjaman modal karena bank menolak memberikan dananya, ketersediaan bahan baku akibat PSBB adalah mengikuti arahan pemerintah untuk terus berinovasi, sabar menanti perubahan masyarakat beralih pada pembelian secara online. 


\section{Saran}

1. Dibutuhkan adanya komitmen pemerintah secara terus menerus untukmemberikansemangat, penyuluhan, pemberian insentif, membuka peluang pasar dan melakukan bentuk/pola usaha UMKM didukung oleh aturan yang mendukung ketertiban usaha.

2. Komitmen terus menerus dari pelaku UMKM untuk memahami kebiasaan konsumen yang belum terbiasa memanfaatkan platform belanja online dengan berinovasi masa pandemi Covid-19, agar bangkit dengan inovasi dan teknologi menyesuaikan pola usahanya dengan kebiasaan sikap masyarakat. Memiliki prioritas program baik secara jangka pendek juga jangka panjang yang bersifat dorongan kepada masyarakat/konsumen beralih pada sistem belanja online, juga melebarkan kerjasama terkait dengan penggunaan inovasi dan teknologi untuk memberikan kemajuan persaingan usahanya melalui perubahan mutu ke arah lebih baik, produksi, termasuk pembungkusan produksi untuk dijual serta mempertajam pengetahuan tentang bagaimana produksi dipasarkan juga sistem pemasarannya.

\section{Ucapan Terimakasih (Acknowledgement)}

Terimakasih kepada Bapak Yuwono Prianto, S.H, M.H dan Ibu Jeane Neltje S.H.,M.H.,APU.,Dr.,Prof., selaku dosen yang telah membimbing kami dalam pembuatan artikel ini, sehingga kami dapat menyelesaikan pembuatan artikel ini dengan sangat baik.

\section{REFERENSI}

Arianto, B. (2020). "Pengembangan UMKM digital di masa pandemi covid-19". ATRABIS: Jurnal Administrasi Bisnis. 6.(2) 233-247

Anonym. (2021). "dukungan pemerintah bagi umkm di masa pademi" https://www.ekon.go.id/publikasi/detail/2939/dukungan-pemerintah-bagi-umkm-agarpulih-di-masa-pandemi diakses pada tanggal 28 April 2021

Agus eko Nugroho. (2020). "survei kinerja umkm di masa pandemi" http://lipi.go.id/berita/surveikinerja-umkm-di-masa-pandemi-covid19/22071 diakses pada tanggal 30 Juni 2020

Anonym. (2017). "hasil pendaftaran listing usaha perusahaan sensus ekonomi" https://bekasikota.bps.go.id/pressrelease/2017/06/20/122/hasil-pendaftaran--listing-usaha-perusahaan--sensus-ekonomi-2016-di-kota-bekasi.html diakses pada tanggal 20 Juni 2017

Anonym. (2020). "apa itu banpres produktif usaha mikro?" https://www.deliserdangmall.com/majalah/apa-itu-banpres-produktif-untuk-usaha-mikrosyarat-dan-siapa-saja-lembaga-pengusulnya-cek-informasinya-disini diakses pada tanggal 01 September 2020

Bardan, A., Waseso, R. (2020). "Banpres produktif ditambah 3 juta". UKM. Kontan.co. Jakarta. $\quad$ https://insight.kontan.co.id/news/tandas-sejak-6-oktober-banpres-produktifditambah-3-juta-ukm diakses pada tanggal 08 Oktober 2020

Cahyadi, C. (2021). "Pelatihan Pembuatan Design Digital Marketing bagi UMKM untuk Meningkatkan Wawasan dan Pendapatan Masyarakat Desa Cikarageman, Setu, Bekasi”. Jurnal Pengabdian Pada masyarakat. 6, No. 2. 372-380.

Fadhillah, N. (2021). "Optimalisasi Umkm Dalam Pemanfaatan Teknologi Digital Di masa Pandemi Covid-19 di lingkungan Kecamatan Cibitung, Kabupaten Bekasi.”. Devosi..2.(2): 2775-9091

Hariyanti, D. (2021). "Usaha Mikro Kecil Bangkit”. Katadata. Jakarta.

https://katadata.co.id/ariemega/berita/6028c295b01cd/2021-usaha-mikro-dan-kecil-bangkit diakses pada tanggal 14 Februari 2021

Hidayati, Nur. (2021). "Merubah Tantangan Sebagai Peluang di Masa Pandemi Bagi Komunitas 
UMKM Naik Kelas Kota Bekasi”. Jurnal Abdimas Ekonomi dan Bisnis.1.(1).2775-5134

Humas. (2020). "penyaluran banpres produktif usaha mikro capai 100 persen" https://setkab.go.id/teten-masduki-penyaluran-banpres-produktif-usaha-mikro-capai-100persen/diakses pada tanggal 07 Oktober 2020

Ihsanuddin. (2020). "Jokowi luncurkan bantuan produktif untuk usaha kecil". Kompas.com. Jakarta. https://nasional.kompas.com/read/2020/08/24/14052941/jokowi-resmi-luncurkanbantuan-produktif-untuk-usaha-kecil diakses pada tanggal 24 Agustus 2020

Ibeng, P. (2021). "Pengertian UMKM". Pendidikan.co.id. Jakarta https://pendidikan.co.id/pengertian-umkm/ diakses pada tanggal 26 Agustus 2021

Junedi. (2020). "Identitas Merek, Inovasi Produk dan Orientasi Pasar Study UMKM Hijab di Kabupaten Bekasi”. Jurnal Ekonomi Manajemen Bisnis.1.(2)2716-0238

Muhammad Azzam . (2020). "jumlah penerima banpres umkm di kabupaten Bekasi" https://wartakota.tribunnews.com/2020/10/30/jumlah-penerima-banpres-umkm-dikabupaten-bekasi-mencapai-146390-orang diakses pada tanggal 30 Oktober 2020

Munthe, R. Rahadi, D. (2021). "inovasi dan kreativitas umk di masa pandemi (studi kasus di kabupaten bekasi)" Jurnal Magisma.IX .(1)

Puspita, R. (2020). "UMKM Bekasi bertahan saat pandemic covid-19" . Republika. Bekasi. https://republika.co.id/berita/q8pbik428/umkm-di-kabupaten-bekasi-bertahan-saatpandemi-covid19 diakses pada tanggal 13 April 2020

Sukmawijaya, A. (2020). " $84 \%$ pendapatan UMKM anjlok". Kumparan bisnis. Jakarta. $\quad$ https://kumparan.com/kumparanbisnis/survei-bps-84-persen-umkmpendapatannya-anjlok-selama-pandemi-1uCjkE3Px28/2 diakses pada tanggal 15 September 2020

Suci, Y. (2017). "Perkembangan umkm (usaha kecil dan menengah di Indonesia)". Jurnal Ilmiah Cano Ekonomos.6.(1)

Republik Indonesia, Undang-Undang Nomor 20 Tahun 2008 tentang Usaha Mikro, Kecil, dan Menengah, Lembaran Negara Nomor 93 ; Tambahan Lembaran Negara Republik Indonesia Nomor 4866 Tahun 2008. 